\title{
SMALL TERRESTRIAL MAMMALS AND BATS OF MELALEUCA AND CLAYTONS, SOUTHWESTERN TASMANIA
}

\author{
by Robert J. Taylor and Michael D. Comfort
}

(with one table and one text-figure)

TAYIoR, R.J. \& COMFORT, M.D., 1993 (31:viii): Smail terrestrial mammals and bats of Melaleuca and Claytons, southwestern Tasmania. Pap. Proc. R. Soc. Tasm. 127: 33-37. https://doi.org/10.26749/rstpp.127.33 ISSN 0080-4703. Forest Practices Unit, Forestry Commission, 30 Patrick Street, Hobart, Tasmania 7000 (RT ); Parks and Wildlife Section, Department of Environment and Land Management, GPO Box 44A, Hobart, Tasmania 7001 (MC).

A survey of small terrestrial mammals and bats was undertaken in two areas of southwestern Tasmania: around Melaleuca, in sedgeland, scrub and woodland communities, and at Claytons in mixed forest. The density of bats was extremely low in comparison with populations in eastern Tasmania. The densities of Rattus lutreolus and Antechinus minimus were greatest in sedgeland/scrub with a dense undergrowth. Pseudomys higginsiwas only captured in mixed forest but is also present around Deny King's garden. Dasyurus viverrinus was most abundant in young sedgeland. Cercartetus nanus was present at both Claytons and Melaleuca. No introduced rodents were trapped, but an outbreak of Rattus rattus had occurred previous to our study. No Mastacomys fuscus were trapped but they have been recorded in a previous study. Fire has an important influence on the composition and structure of the vegetation which, in turn, influences the composition and density of the mammal community.

Key Words: Small mammals, bats, sedgeland, rainforest, fire, southwestern Tasmania.

\section{INTRODUCTION}

The Department of Parks, Wildlife and Heritage (now Environment and Land Management) chose two areas in the Tasmanian Wilderness World HeritageArea(centred around Pelion Plains AMG 42083685 and Melaleuca 43221920 [in southwestern Tasmania]) to be used as baseline study sites. Extensive biological surveys are to be undertaken in these areas, so that any long-term changes can be monitored. This paper reports the results of a survey of small terrestrial mammals and bats around Melaleuca and in mixed forest at Claytons, northwest of Melaleuca, on the shores of Bathurst Harbour.

\section{METHODS AND STUDY AREAS}

Surveys were undertaken around Melaleuca between 25 February and 4 March 1991, and at Claytons between 1 and 3 March 1991. At Melaleuca, work was undertaken in different aged stands of sedgeland, around the walkers huts and in the garden of Deny King, who was a long-term resident of the area. At Claytons, trapping occurred in mixed forest and around the house.

The following vegetation/habitat types were recognised: MIXED FOREST - Forest with a canopy of Eucalyptus nitida and rainforest species (Nothofaguscunninghamii, Andopetalum biglandulosum, Eucryphia lucida, Phyllocladus aspleniifolis). The undergrowth was usually open but with some patches of A. biglandulosum, Cenarrhenes nitida and Anopterus glandulosus. Ground cover consisted mostly of mosses and Blechnum wattsii, with some Gabnia grandis and Gleichenia dicarpa.

Sclerophyll. Woodland with Tall Scrub - Open Eucalyptus nitida woodland with tall dense tea-tree scrub (Melaleuca squarrosa and Leptospermum scoparium). Undergrowth was sparse with dense leaf litter and a few small scattered Gahnia grandis.

TAll SCRUB - Tea tree scrub greater than $3 \mathrm{~m}$ tall, some- times with scattered eucalypts overtopping. The undergrowth showed some effects of shading by tea-tree but not to the extent of nearly complete elimination, as in the previous community. Dense patches of undergrowth were scattered through this community. Species dominant in the undergrowth included Gabnia grandis, Gleichenia dicarpa, Restio tetraphyllus, Bauera rubioides, Calorophus elongatus, Gymnoschoenus sphaerocephalus, Tasmannia lanceolata, Lepidosperma elatius and Boronia citriodora.

Tall Sedgeland - Tea-tree shrubs 1.5-3 m tall, with Gymnoschoenus sphaerocephalus usually more prominent in the undergrowth compared with the previous community. Effects of shading of the undergrowth were not prominent. Common understorey plants included G. sphaerocephalus, Gabnia grandis, Restio tetraphillus, Gleichenia dicarpa and Calorophus elongatus.

SEDGELAND - Height of vegetation was $0.5-1.5 \mathrm{~m}$. Tea-tree and Gymnoschoenus sphaerocephalus dominant.

Low SEDGELAND - Height of vegetation less than $0.3 \mathrm{~m}$. Open ground was present between plants. Included recently burnt areas of sedgeland with dead $2 \mathrm{~m}$ tall stems of tea-tree. HUTS - This included trap locations beside, under, or close to the ranger's hut or bushwalkers huts.

King's Garden - This included areas around Deny King's garden and sheds where introduced plants (e.g. Fuchsia) were present. Undergrowth of some areas was dominated by Blechnum nudum, Dicksonia antartica or Hypolepis rugosula. A large vegetable garden was present with apple and pear trees. Areas trapped included a shed with much spilt birdseed and the ground underneath the bird feeder, near the bird observatory.

Claytons - Traps were placed in the garden and a shed in the immediate vicinity of the house at Claytons.

The age of the sedgeland, scrub and woodland stands was assessed from ring counts from stem portions taken at ground level from Melaleuca squarrosa, Leptospermum scoparium, and L. glaucescens (Jarman et al. 1988).

Trapping of small terrestrial mammals was undertaken with Elliot and break-back traps. Elliots were baited with a 
mixture of peanut butter, rolled oats and oil. Break-backs were set with walnuts. In all, 178 trap sites in lines were set out, with between 10 and $25 \mathrm{~m}$ between traps. Traps were set for three to six nights. A single Elliot trap was placed at every trap site except one site in low, open sedgeland and four sites around the house at Claytons, where only a breakback was set. Two Elliot traps were placed in the seed shed and at the bird feeder in Deny King's garden. Break-back traps were placed nearby selected trap locations for the last one or two nights that the trap lines were set out, in order to try to catch species such as Mastacomys fuscus and Sminthopsis leucopus, which could be trap shy. There were a total of 631 trap nights for Elliots and 78 trap nights for break-backs.

The survey of bats utilised harp traps, mist nets and ultrasonic detectors. Locations suitable for the use of harp traps and mist nets were rare. The harp trap was used in two locations: near a machinery shed south of the airstrip (night of 25/26 February) and on the path from the bird observatory to Deny King's garden sheds, just near the edge of the tall scrub-open buttongrass boundary (nights of 17/18 February, 1/2, 2/3, 3/4 March). A mist net was set in King's vegetable garden on two nights: 27 February, 1945 to 2100 EST and 2 March, 1940 to 2045 EST. An ultraviolet light was placed nearby, in an attempt to attract insects and thence bats. Ultrasonic detectors were used to pick up the echolocation calls of bats. A detector was placed at four locations: on top of the water tank at the house at Claytons on the night of on 25 February, on the bridge where the South Coast Track crosses Melaleuca Creek on 26 February and on the roof of Deny King's painting shed on 2 March. The output from these was taped for $45 \mathrm{~min}$ commencing at 2000 EST. A bat detector (Anabat II, Titley Electronics) was also usually carried during spotlighting. Five hours $15 \mathrm{~min}$ of spotlighting were undertaken, $70 \mathrm{~min}$ at Claytons and the rest around Melaleuca.

The Anabat computer program written by C. Corben (Queensland Forest Service) was used to produce a frequency-time display of a bat call, after passing the recording through a zero crossing analysis interface module 1 March, next to ponds in buttongrass south of the airstrip

(Titley Electronics). The bat species was identified from the display of the call by comparing it with the calls of all species of Tasmanian bats recorded in eastern and northwestern Tasmania (A. Duncan \& R. Taylor, pers. obs.).

Weather conditions during the study were generally mild but cold rainy weather occurred on the night of 28 February and the following day.

\section{RESULTS}

\section{Age of Vegetation Types}

Ages of stands sampled from representative sites where trapping was undertaken were as follows: low, open sedgeland, $1-1.5$ yrs (C. Arthur, pers. comm.); sedgeland, $14.2 \pm 1.9$ (5) $(\mathrm{x} \pm \mathrm{SD}[\mathrm{N}])$; tall sedgeland, $19.8 \pm 2.3(8)$; tall scrub $32.6 \pm$ 5.2 (5); sclerophyll woodland, $35 \pm 5.6$ (3) and mixed forest, 250 yrs (Brown \& Podger 1982).

\section{Small Mammals}

Trapping results for small terrestrial mammals are given in table 1. Density indices for each species in natural habitats are graphed in figure 1 as a function of time since firing. Rattus lutreolus densities were highest in sedgeland and scrub with a well-developed understorey. In areas with a sparse to very open undergrowth, no individuals were captured. Densities were lower in mixed forest than in scrub and sedgeland. Densities in King's garden were high. Antechinus minimus was trapped in older sedgeland, in scrub and in areas of King's garden with a well-developed undergrowth. Pseudomys higginsi was only trapped in mixed forest. However, two individuals were trapped by M. Driessen and M. Comfort in late May 1991 in tall sedgeland near the Ranger Hut, only 1-2 m from trap locations used in our study. Dasyurus viverrinus was more abundant in the younger ages of sedgeland and was not trapped in mixed forest. Cercartetus nanus was trapped on Deny King's kitchen bench and an individual was found in the bathtub at the house at Claytons. No terrestrial mammals were observed during spotlighting.

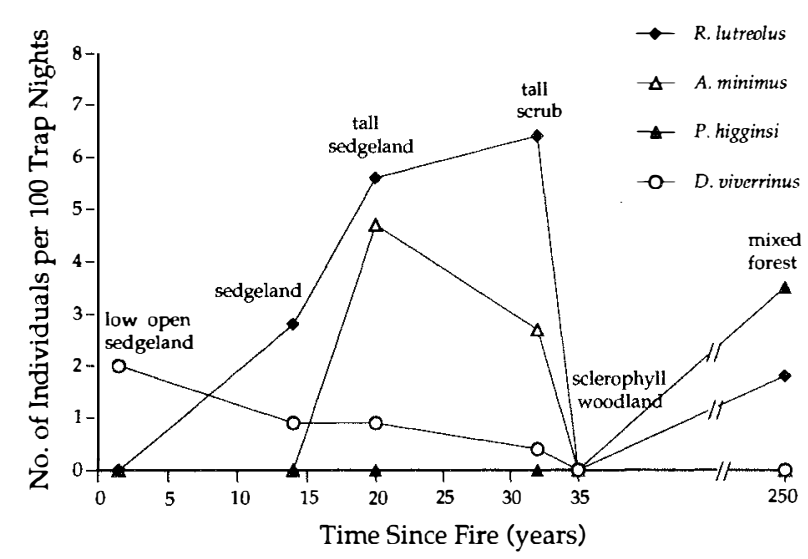

FIG. 1 - Density (number of different individuals/100 trap nights) of small terrestrial mammals in different vegetation types as a function of time since fire.

\section{Bats}

Output from the bat detectors was recorded for $3 \mathrm{~h}$ and detectors were monitored for a further $4 \mathrm{~h} 25 \mathrm{~min}$ whilst spotlighting. Two bat passes were detected. One of these was heard (but not recorded and was thus not identifiable) during spotlighting at the painting shed in King's garden. The other was recorded at the bridge over Melaleuca Creek. This latter call most closely resembled that of Eptesicus regulus. The rate of detection of bats was 0.24 passes per hour.

\section{DISCUSSION}

Trapping for bats at other sites in western Tasmania has found species diversity to be low (Taylor \& O’Neill 1986). Taylor et al. (1987) thought that the cold conditions and high rainfall in western and southwestern Tasmania would limit populations in comparison with eastern Tasmania. The survey of bats at Melaleuca and Claytons revealed that there was a very low density of bats present. The number of bat 
TABLE 1

Trapping results*

\begin{tabular}{|c|c|c|c|c|c|c|c|c|c|c|c|c|c|c|}
\hline \multirow[t]{2}{*}{ Habitat } & \multicolumn{3}{|c|}{ Number of trap nights } & \multicolumn{2}{|c|}{ Traps set off } & \multicolumn{2}{|c|}{ Rattus lutreolus } & \multicolumn{2}{|c|}{ Antechinus minimus } & \multicolumn{2}{|c|}{ Pseudomys higginsi } & \multicolumn{2}{|c|}{ Dasyurus viverrinus } & \multirow{2}{*}{$\frac{\text { Bird }}{\begin{array}{c}\text { Total } \\
\text { captures }\end{array}}$} \\
\hline & Elliott & $\begin{array}{l}\text { Break- } \\
\text { back }\end{array}$ & Total & $\begin{array}{l}\text { Bait } \\
\text { in }\end{array}$ & $\begin{array}{l}\text { Bait } \\
\text { taken }\end{array}$ & $\begin{array}{c}\text { Total } \\
\text { captures }\end{array}$ & $\begin{array}{l}\text { Individuals/ } \\
100 \text { trap nights }\end{array}$ & $\begin{array}{c}\text { Total } \\
\text { captures }\end{array}$ & $\begin{array}{l}\text { Individuals/ } \\
100 \text { trap nights }\end{array}$ & $\begin{array}{c}\text { Total } \\
\text { captures }\end{array}$ & $\begin{array}{l}\text { Individuals/ } \\
100 \text { trap nights }\end{array}$ & $\begin{array}{c}\text { Total } \\
\text { captures }\end{array}$ & $\begin{array}{l}\text { Individuals/ } \\
100 \text { trap nights }\end{array}$ & \\
\hline $\begin{array}{l}\text { Low } \\
\text { sedgeland }\end{array}$ & 39 & 10 & 49 & 7 & 14 & 0 & 0 & 0 & 0 & 0 & 0 & 1 & 2 & 2 \\
\hline Sedgeland & 107 & 2 & 109 & 5 & 39 & 4 & 2.8 & 0 & 0 & 0 & 0 & 1 & 0.9 & 1 \\
\hline $\begin{array}{l}\text { Tall sedge- } \\
\text { land }\end{array}$ & 91 & 16 & 107 & 0 & 5 & 17 & 5.6 & 8 & 4.7 & 0 & 0 & 1 & 0.9 & 1 \\
\hline Tall scrub & 230 & 34 & 264 & 14 & 51 & 40 & 6.4 & 13 & 2.7 & 0 & 0 & 1 & 0.4 & 3 \\
\hline $\begin{array}{l}\text { Sclerophyll } \\
\text { woodland }\end{array}$ & 34 & 2 & 36 & 2 & 1 & 0 & 0 & 0 & 0 & 0 & 0 & 0 & 0 & 0 \\
\hline $\begin{array}{l}\text { Mixed } \\
\text { forest }\end{array}$ & 57 & 0 & 57 & 1 & 0 & 2 & 1.8 & 0 & 0 & 2 & 3.5 & 0 & 0 & 0 \\
\hline $\begin{array}{l}\text { King's } \\
\text { garden }\end{array}$ & 58 & 6 & 64 & 2 & 2 & 7 & 4.7 & 2 & 3.1 & 0 & 0 & 0 & 0 & 0 \\
\hline Huts & 15 & 0 & 15 & 0 & 3 & 0 & 0 & 0 & 0 & 0 & 0 & 0 & 0 & 0 \\
\hline Claytons & 0 & 8 & 8 & 1 & 3 & 0 & 0 & 0 & 0 & 0 & 0 & 0 & 0 & 0 \\
\hline
\end{tabular}

${ }^{*}$ For the mammals, both total captures and the number of different individuals are given. 
passes recorded in dry forest in eastern Tasmania at a comparable time of year and time of night (R.J. Taylor \& N.M. Savva, pers. obs.) was 80 times greater than that recorded during the present study. We recorded the presence of E. regulus during this study. M. Schultz and K. Menkhorst have previously recorded the presence of both E. regulus and Nyctophilus geoffroyi at Melaleuca (Taylor et al. 1987).

Both Rattus lutreolus and Antechinus minimus were most abundant in sedgeland/scrub areas with a dense ground cover. The sequence from low, open sedgeland through to mixed forest represents a time sequence of age since firing (Brown \& Podger 1982, Jackson 1968). Populations of both species thus build up as the undergrowth recovers after fire but decline when ground cover dwindles due to shading from the canopy. Rattus lutreolus was present at lower densities in mixed forest than in sedgeland with dense ground cover. Ground cover is usually sparse in mixed forest but fallen logs, ferns and some shrub cover occur. Norton (1987) has shown that $R$. lutreolus densities are correlated with vegetation cover less than $0.5 \mathrm{~m}$ high and the amount of monocotyledonous food material present. Taylor et al. (1985) also found densities of $R$. lutreolus in rainforest (non-disturbed areas) were lower than in sedgeland with a dense undergrowth.

No Antechinus were trapped in the mixed forest. A further 73 trap nights in early February also failed to detect any Antechinus in this habitat (M. Comfort \& M. Holdsworth, pers. obs.). Antechinus swainsonii is expected from this habitat. However, trapping intensity was probably lower than required to pick up the presence of this species. Taylor et al. (1985), for example, obtained no $A$. swainsonii in 549 trap nights in November and only one in 355 trap nights in January in rainforest in the Upper Henty River Region in western Tasmania. It would be interesting to undertake further trapping to see whether $A$. swainsonii or $A$. minimus were present in the mixed forest. Green (1979a) has found A. minimus in rainforest in northwestern Tasmania in the absence of $A$. swainsonii. The patches of mixed forest at Claytons are small (Brown \& Podger 1982), and if populations of $A$. swainsonii were to die out here it would be difficult for the species to reinvade, as the area is isolated from other suitable habitat. In the absence of $A$. swainsonii, A. minimus may be able to utilise rainforest. Such competition between Antechinus species, influencing their habitat use, has been documented by Dickman (1986). A. swainsonii was caught by T. Pye (pers. comm.) in wet sclerophyll forest between Melaleuca and Cox Bight.

Pseudomys higginsi was trapped by us only in mixed forest. T. Pye (pers. comm) also did not catch this species around Melaleuca but did trap it in wet sclerophyll forest between Melaleuca and Cox Bight. However, a specimen was obtained from Deny King which he had found near his house. He commented that he saw this species regularly but less frequently than $R$. lutreolus. Two individuals were trapped by $M$. Driessen and M. Comfort (pers. comm.) in tall sedgeland near the ranger's hut, two months after our study. It thus appears that a population exists in the vicinity of Deny King's house and nearby sedgeland. It seems that the species does not occur in other sedgeland areas sampled, or that numbers here are very low. Taylor et al. (1985), in the Upper Henty River region, and Hocking \& Guiler (1983), in the Lower Gordon River region, found P. higginsi in sedgeland. (Hocking \& Guiler [1983] actually refer to some of these communities as shrubland.) Densities are, however, three times greater in rainforest (Taylor et al. 1985). It may be that sedgeland is a suboptimal habitat which is utilised only when other, more suitable habitats are present in an area. In this situation, individuals dispersing from other more suitable habitat can provide a "rescue effect" (Brown \& Kodric-Brown 1977) for sedgeland populations. At Melaleuca, sedgeland dominates. The unnatural conditions in King's garden may bolster food for this species here compared with normal sedgeland situations, but population density is still low.

The preference of Dasyurus viverrinus for younger ages of sedgeland is in accord with findings for both wet sclerophyll (Hocking \& Guiler 1983) and dry sclerophyll forest (Driessen et al. 1991), where numbers have been shown to increase after an area is burnt and then decline as the undergrowth recovers. It is probably easier for $D$. viverrinus to hunt in the more open undergrowth of young sedgeland and it is also possible that some invertebrate groups used as food would be more abundant in younger stages of sedgeland.

Cercartetus nanus is associated with areas of wet forest and has not been recorded from sedgeland (Green 1973). This species was thus expected from the wet forest at Claytons. However, it was also trapped in Deny King's kitchen. The unnatural conditions in the garden may allow it to persist around Melaleuca. Our trapping methods were not suitable to detect $C$. lepidus but it has previously been recorded by Deny King at Melaleuca (Queen Victoria Museum records). C. lepidus is undoubtedly present in sedgeland here as its presence in this habitat has been noted elsewhere (Green 1979b). A study of the relationship between sedgeland age and $C$. lepidus populations is warranted, in order to assess the implications of prescribed burning of sedgeland in the area.

Mastacomys fuscus is only present in older stands of sedgeland (Hocking \& Guiler 1983). The species was trapped by T. Pye (pers. comm.) in sedgeland near the walking track between the airstrip and the ranger's hut. However, no evidence of its occurrence was found by us. It has been trapped in sedgeland areas alongside streams, near the Scotts Peak Road (Driessen \& Comfort 1991) and in the Norfolk Range region in northwestern Tasmania (Slater 1992). These areas appear to be similar to some we trapped. Break-back traps were used by us in the hope of trapping this species if it avoided the Elliot traps. However, this tactic did not prove successful. The species has been caught elsewhere in both Elliot and break-backs with the same bait mixtures as we used. The sedgeland in the vicinity of the location where T. Pye trapped $M$. fuscus has been burnt since he conducted his trapping, and it is possible that suitable habitat for the species may have been destroyed.

Introduced rodents are generally thought to be absent from southwestern Tasmania and neither Hocking \& Guiler (1983) nor Taylor et al. (1985) recorded them. We caught no live individuals. However, Deny King had a preserved specimen of Rattus rattus that he had trapped several months previous to our study. He reported the outbreak of the species at this time as being the first he had known. He thought the species might have been introduced in the cargo of a Caribou aircraft, as the outbreak occurred after the landing of one of these at Melaleuca.

Fire is the most important factor influencing the terrestrial mammal populations in the study area via its effect on the vegetation. Different species were found to favour different ages of sedgeland and to be dependent on vegetation types which required different fire-free periods. Fire regimes in sedgeland and the protection of the small pockets of fire- 
sensitive vegetation are the most important factors which need to be considered by the Parks and Wildlife Section in determining management of the mammal populations around Melaleuca.

\section{ACKNOWLEDGEMENTS}

We would like to thank Steven Smith for the invitation to undertake this work. Local knowledgeand specimens provided by the late Deny King greatly assisted our study. Chris Arthur and Mark Holdsworth provided boat transport to Claytons. M. Driessen and T. Pye kindly allowed us to quote their unpublished data. M. Brown provided comments on a previous draft. Funding was provided by the Department of Parks, Wildlife and Heritage (now Environment and land Management). R.J. Taylor would like to thank the Forestry Commission for allowing him time to undertake this study.

\section{REFERENCES}

BRown, J.H. \& Kodric-Brown A., 1977: Turnover rates in insular biogeography: effect of immigration on extinction. Ecology 68: 445-449.

Brown, M.J. \& PODGER, F.D., 1982: Floristics and fire regimes of a vegetation sequence from sedgeland-heath to rainforest at Bathurst Harbour, Tasmania. Aust. J. Bot. 30: 659-676.

DiCKMAN, C.R., 1986: An experimental study of competition between two species of dasyurid marsupials. Ecol. Monogr. 56: 221241.

Driessen, M.N. \& COMFORT, M.D., 1991: Small mammal trapping in sedgeland at McPartlen Pass: A new location for Mastacomys fuscus. Tasm. Nat. 107: 1-5.
Driessen, M. M., Taylor, R.J. \& Hocking, G.J., 1991: Trends in abundance of three marsupials after fire. Aust. Mammal. 14: 121-124.

GreEn, R.H., 1973: THE MAMMALS OF TASMANIA. Mary Fisher Bookshop, Launceston.

GreEn, R.H., 1979a: A survey of the vertebrate fauna of the Sumac forest and the Dempster Plains, north-west Tasmania. Rec. Queen Vic. Mus. 65: 1-9.

GreEn, R.H., 1979b: The little pygmy possum Cercartetus lepidus in Tasmania. Rec. Queen Vic. Mus. 68: 1-12.

HockInG, G.J. \& Guiler, E.R., 1983: The mammals of the Lower Gordon River Region, south-west Tasmania. Aust. Wildl. Res. 10: 1-23.

JACKSON, W.D., 1968: Fire, air, earth and water - an elemental ecology of Tasmania. Proc. Ecol. Soc. Aust. 3: 9-16.

Jarman, S.J., Kantvilas, G. \& Brown, M.J., 1988: A preliminary study of stem ages in buttongrass moorland. Res. Rep. Tas. For. Res. Counc. 3. Hobart.

NORTON, T.W., 1987: The ecology of small mammals in northeastern Tasmania I. Rattus lutreolus velutinus. Aust. Wildl. Res. 14: 425-433.

SlATER, J., 1992: Vertebrates. In Harries, D.N.(Ed.): FORGOTTEN WILDERNESS: NORTH WEST TASMANIA. Tasmanian Conservation Trust, Hobart: 251-297.

Taylor, R.J., Bryant, S.L., Pemberton, D. \& Norton, T.W., 1985: Mammals of the Upper Henty River Region, Western Tasmania. Pap. Proc. R. Soc. Tasm. 119: 7-14.

TAYlor, R.J. \& O'NeILl, M.G., 1986: Composition of the bat (Chiroptera: Vespertilionidae) communities in Tasmanian forests. Aust. Mamm. 9: 125-130.

Taylor, R.J., O’Neill, M.G. \& Reardon, T., 1987: Tasmanian bats: Identification, distribution and natural history. Pap. Proc. R. Soc. Tasm. 121: 109-119.

(accepted 9 December 1992) 